\title{
Corporate board failure in Zimbabwe: Have non - executive directors gone to sleep?
}

\author{
${ }^{1}$ Sifile Obert, ${ }^{2}$ Professor Susela Devi K. Suppiah, ${ }^{3}$ Mabvure Joseph Tendai, \\ ${ }^{4}$ Chavunduka M. Desderio, ${ }^{5}$ Dandira Martin, \\ ${ }^{1,3,4,5}$ Chinhoyi University of Technology \\ ${ }^{2}$ Unitar International University
}

\begin{abstract}
:
Manuscript Type: Review

Research Question / Issue: The review focuses on board failure especially in the developing world, and in particular, Zimbabwe. The review asks pertinent questions: Why are boards failing? How are boards populated? What are the characteristics that determine selection to the board? Who selects directors?

Research Findings / Insights: The review establishes that there is need for a corporate governance code and awareness of corporate governance practices in Zimbabwe. Directors are usually selected through the influence of the CEO and such directors have weak oversight on the performance of the CEO. Some characteristics that determine director selection are gender, age, educational qualifications, experience and financial expertise.

Theoretical / Academic Implications: Directors are stewards who have to be accountable to all stakeholders. Practitioner / Policy Implications: There is need to establish how directors are selected in light of the high rate of company and board failures. That directors are also chosen by the CEO is worrying. The selection process should yield capable, independent and diverse directors who can satisfy the expectations of a wide spectrum of stakeholders.
\end{abstract}

Key words: Corporate Governance, Board, Directors, Director Selection, Zimbabwe.

\section{Introduction}

That board efficacy has been exposed by the collapse of iconic corporate giants that were the envy of investors and competitors, is not debatable. The board of directors is the epitome of corporate governance. Firm survival hinges on an effective board with effective and controlling functions (Cadbury, 1992). While the Western and Eastern countries are far advanced in terms of the development and implementation of corporate governance codes, Africa is lagging far behind (Rossouw, 2005). Zimbabwe does not have a corporate governance code (at the time of publishing this article). Zimbabwean companies use the Companies Act Chapter 24:03 and some provisions of codes like the South African Corporate Governance Code also called the King Report. The historical and iconic Cadbury Code and its successors, the UK Combined Code on Corporate Governance are also a source of corporate governance prescriptions that are used by Zimbabwean companies.

\subsection{Background of the research study}

A plethora of local, regional and international company collapses, judicial management, fraud and corruption are ills that have characterised the corporate landscape. The ensuing sections chronicle corporate failures that show board failure as the guarantor of good corporate governance. The paradox is that sometimes companies that looked very healthy would collapse without any hint that they were facing difficulties (Heenetigala and Armstrong, 2009). Of historical significance are world renowned companies like Enron, WorldCom and Lehman Brothers (Blancheton et al, 2011, Jeter, 2003). Questions can be asked: Where were boards when companies were collapsing? What kind of directors populated those boards? Were the directors aware of their duties?

\subsection{Corporate failures in Zimbabwe}

Several companies have faced difficulties associated with board failure. Of note are companies like Air Zimbabwe, PSMAS, ZBC, African Renaissance Bank (AFRE), BCCI, UMB Bank, ENG Capital and Barbican Bank. The major causes of corporate scandals were centred on poor oversight and lack of proper monitoring of the $\mathrm{CEO}$ and executive directors by the board leading to corporate governance breaches. While board structures were in place in the organisations, the board of directors had the biggest share of the blame for its failure to monitor management.

Due to the widespread and the seemingly never - ending spectre of scandals, the Zimbabwean Government notes with concern the plethora of scandals and company failures bedevilling the country and 
affecting the people and the economy at large. This has led to the proposal to form a parliamentary committee to deal with corruption, scandals and misdemeanours perpetrated by those in fiduciary positions (see The Herald of 3 March of 2014). To buttress efforts by government, the Institute of Chartered secretaries and Administrators in Zimbabwe (ICSAZ) has started promoting good corporate governance by hosting corporate governance awards called 'Excellence in Corporate Governance Award' and 'The Chartered Secretary of the Year award'. These efforts seek to promote corporate governance and effective board practices in Zimbabwe.

\subsection{Corporate governance landscape in Zimbabwe}

\section{Literature Review}

Governance issues are not alien to Zimbabwe as traditional chiefs have been recognised as custodians and fountains of knowledge of grassroots democracy as they make consultations with their council machinery or court system before taking any decision (Makahamadze, Grand and Tavuyanago, 2009). Pre-colonial chiefs were custodians of peace and human rights. Human life was viewed as sacred and annoyance of innocent people would evoke punishment from the ancestors (ibid). The end result was equitable distribution of resources, justice and harmony.

Chiefs have played a significant governance role since time immemorial. The chief (mambo or ishe) rules with the aid of his headmen (vanaSadunhu). He has a team of experts (makurukota) who are fountains of knowledge in various areas of life. The chief's court (dare) is like the board and the chief performs the role of chairman of the dare. The sadunhu and makurukota, who assist the chief in adjudicating cases at the chief's court, are the directors. The sadunhu are experts in various issues like marriage discord (kunetsana mudzimba kana kurambana), thefts, adultery, cattle disputes involving stray cattle destroying another person's field (kudyisirana minda) and impregnating a girl and refusing to marry her (kumitisa kana kupwanya ruzhowa).

Zimbabwean indigenous culture comes in with support for boards with wise sayings like the following: Chara chimwe hachitswanyi inda - which means that one finger, cannot crush lice (Mbigi and Maree, 1995). Rume rimwe harikombi churu - meaning that one man cannot successfully hunt alone. Just like boards are a communal and group effort, hunting is easy if communally done. Chances of catching the prey are more when you are many. Zano marairanwa - which translates to the fact that ideas are best if shared as ideas from many people are better than ideas from one mind. All these proverbs or wise sayings point towards the importance of the board as a forum that ensures that there is order and harmony in the community.

Research on board failure and corporate governance in Zimbabwe is scanty. The main cause of corporate failures and fraud in Zimbabwe has been blamed on ineffective internal controls that are used in measuring the compliance levels of managers in the day to day running of the financial institutions by the board (Njanike et al., 2011). When one speaks of management it is about internal controls. Laxity of implementing effective internal controls, greed and in some instances poor or lack of board supervision emerges as contributors to poor corporate governance in many institutions (ibid).

In a research on internal controls as mechanisms for ensuring good corporate governance, Njanike et al. (2011) found that for the Board of Directors to ensure that systems of internal control continue to operate effectively and efficiently the board must set targets and the board gets updates and reports from executives in meetings. Mangena and Tauringana (2007) opine that in light of the increased emphasis on corporate governance around the world, the Institute of Directors of Zimbabwe (IODZ) has been promoting the principles of good corporate governance by recommending compliance with the recommendations set out in the United Kingdom's Combined Code or the South African King Reports. They also state that the ZSE Listing Rules (2002) incorporate some provisions of the UK's Combined Code and King Reports, and companies are encouraged to adopt either of the two codes.

\subsection{The Board of directors as a corporate governance tool}

Shivdasani and Yermack (1999) opine that a board of directors serves as the mechanism for monitoring the managers of a public corporation. They further state that directors are voted into office by shareholders and have a fiduciary responsibility to protect shareholders' interests. Along with their legal duties of reviewing the corporation's major plans and actions, directors are charged with selecting, compensating, evaluating, and, when appropriate, dismissing top managers.

The board of directors is preoccupied with the monitoring role on behalf of the shareholders (Hashim and Devi, 2008) and has the main duty of leading and directing the firm to achieve corporate goals by closely monitoring management activity so that the interest of the shareholders is well protected (Abdullah, 2004). The board is also regarded as the most powerful and cost effective governance mechanism for monitoring management in pursuing activities that increase a firm's value (Abdullah and Nasir, 2004).

Haspeslagh (2010) contends that the main instrument of corporate governance remains the role and responsibility of the corporate board which carries out the following three tasks: set direction and approve strategy, provide proper performance and risk oversight, selection, development and rewarding of leadership. In 
these tough economic times, investors are becoming more proactive as they cannot afford to leave the governance of their investments to unqualified directors or to special interest groups (Dandira, 2011). Boards are given more power to govern and control the performance of the CEO and the corporation (ibid).

Ayogu (2000) hints that the underlying thesis is that a crisis of governance is basically a crisis of the board of directors and that the problem of corporate governance is concerned with the design of institutions that induce management in their actions, to take into account the welfare of stakeholders-investors, employees, communities, suppliers, and customers. Board members are effectively chosen by the senior executives and thus are answerable to them (ibid). Given that, the shareholders elect the board, but they invariably simply select from the menu of candidates on the proxy statement circulated by management. Therefore, management effectively decides who is nominated. Could this be the Achilles Heel of the Zimbabwean corporate landscape?

\subsection{Director selection}

Procedures for the nomination of directors are triggered by the prevalence of a vacancy on the board or the board is to be expanded (Withers, Hillman and Cannella Jr, 2012). Selection involves the identification and screening of the candidates by a nominating committee composed of either all or a majority of independent directors (Hoskisson, Castleton, and Withers, 2009). After the nominating committee screens the initial candidates, the entire board and CEO often interview them. Those who are found to be suitable for board appointment are formally nominated and voted on by shareholders (Monks and Minow, 2004). A transparent process yields competent independent directors who will responsibly monitor and give counsel to the executive.

\subsection{A Rational Perspective of the Director Selection process}

Withers, Hillman and Cannella Jr, (2012) posit that when a director or directors leave the board, a search to fill the vacancies is initiated. There are a variety of other reasons which trigger vacancies and some of the reasons inter alia are the normal end of a director's term, retirement, resignation, death, board expansion, which may occur in response to the request of a major shareholder, the desire to retain executives secured in an acquisition or merger, the desire to retain executives passed over in a CEO selection process, or a variety of other organizational reasons (ibid). A new company definitely needs a board. The rational economic perspective of director selection assumes that directors serve the best interests of the organization and its shareholders (Nicholson and Kiel, 2004). This hypothetical position is that those who are experts in board functions would thus be the ones who find their way into the boardroom to contribute towards good corporate governance and organizational performance.

\subsection{Social capital perspective of director selection}

- Specific knowledge, skills, experience. Directors are expected to be fountains of knowledge, skills, and relevant experiences.

- An individual's social capital. Cannella (2008) posits that when a director exhibits the ability to carry out board functions that shows his social capital thus the selection of directors should be done fully well knowing the social capital that will be gained by associating with that director.

- Director reputation. The reputation of a director has a direct bearing on the reputation of a company. Good reputation of directors attracts investors and gives them assurance that their investments are safe (Deutsch and Ross, 2003).

- Other directorships. A director's other board appointments (also called cross or board interlocks) are also likely to influence selection. Experience gained from sitting on other boards has the effect of bringing other experiences to the board (Keys and $\mathrm{Li}, 2005$ ). However the maximum directorships which can make a director effective remain a critical issue.

- Gender. A board diversity proxy that has received a lot of research attention has been the issue of women presence on boards. Major corporate collapses of the magnitude of Enron, Parmalat and WorldCom have been dominated by male boards. The entering of women directors on the boards is seen as a panacea to the never ending failures orchestrated by very ambitious and seemingly uncontrollable males (Singh, 2007).

\subsection{A Socialized Perspective of the Director Selection Process}

In the socialized perspective, the director nomination and selection processes are driven by the need to select directors with the same characteristics as the incumbent directors so that the group can affiliate with each other (Westphal and Stern, 2007). This is the same as choosing peers who share the same dispositional characteristics. This may be premised on the old adage that 'birds of the same feather fly in the same proximity'. In the Zimbabwean culture they say 'zvikomo zvinotambidzana mhute'.

Research shows that CEOs influence the director selection process so that directors who are inclined to closely monitor management are avoided and those who are likely to be compliant are selected (Finkelstein et al., 
2009). Given the need for a new director, it is widely assumed that the personal attributes of candidates and their fit with the rest of the board are major determinants of director nominations.

Fich and White (2003) find that CEOs in power may seek to bring sympathetic directors into the board. They state that CEOs would exploit board interlocks by sneaking in board members they already affiliate with in other boards. This has the effect of reducing monitoring of management. The CEO runs the risk of being all too powerful and uncontrollable. Carcello, Neal, Palmrose and Scholz (2011) opine that when the CEO is involved in the board selection process, there is a greater risk that a director appears independent without being independent from the company and its inner circle. To counter CEO involvement in director selection, SOX prescribes use of a nomination committee.

Another research by Beasley et al. (2009) finds that engaged board members are already known to have prior personal or business relationships with the CEO and senior management of the companies they serve, although they are taken to be technically independent. The continued failure of CEOs to undertake their fiduciary duties leading to the seemingly never ending corporate difficulties and failures seems to suggest that the director selection process is tainted with irregularities that need to change. Extant research has shown that under previous regulatory regimes board nominees were proposed and approved by the CEO and other members of top management (Glassman, 2003). In some companies, it would appear as if the CEO hires the board instead of the board hiring the CEO (ibid). How then does a CEO become accountable to the directors that he puts in place?

\subsection{Director Demographic Characteristics as selection criteria}

There is little consensus on what kinds of people make the best board members (Johnson, Schnatterly and Hill, 2013). This is premised on the utility value of directors as they monitor and control the affairs of a company (Cadbury, 1992). Major demographic characteristics that researchers focus on include age, educational background, gender, race, and ethnicity (Carpenter, Geletkanycz, and Sanders, 2004). Researchers typically assume that demographic characteristics affect directors' cognition, behaviors, and decision making and subsequently impact firm-level outcomes (Johnson, Schnatterly and Hill, 2012).

\subsubsection{Age}

Ahn and Walker (2005) opine that younger boards are associated with greater strategic change. Golden and Zajac (2001) find that the percentage of directors over age 50 is positively related to strategic change while a study by Platt and Platt (2012) find that the average age of directors in firms that succumb to bankruptcy is significantly lower than in firms that do not, suggesting that older directors have valuable experience.

\subsubsection{Educational level}

Studies show that educational backgrounds can have no (Rose, 2007) or a positive (Kim and Lim, 2010) impact on firm value. Dalziel, Gentry, and Bowerman (2011) find that the advanced educational degrees of outside directors negatively impact Research and Development expenditures but that the number of Ivy League degrees on the board is positively related to such expenditures. Similarly, Wincent et al. (2010) find that the total number of college degrees on the board positively impacts innovative performance. The educational status of directors in Zimbabwe needs to be investigated since research results from elsewhere across the world seem not to agree.

\subsubsection{Gender}

Terjesen, Sealy, and Singh (2009) reviewed 180 academic publications that cumulatively suggest gender diversity affects board dynamics but not the firm's profitability. Bohren and Strom (2010) identify that the evidence on gender diversity is few and conflicting, with studies finding positive, negative, and no relationship between gender and firm value. Scholars offer a number of reasons for this, ranging from endogenous drivers of board composition to industry or cultural differences (Adams and Ferreira, 2009).

\subsubsection{Industry familiarity}

Knowing the intricacies of an industry influences how directors process information and this has a bearing in performance in the boardroom (Johnson et al, 2012).

\subsubsection{Executive experience}

Experience has ever been seen as the best teacher. Directors who have been CEOs bring executive experience to the board, which serves as a benchmarking on which the organization can draw (Johnson et al, 2012). 


\subsubsection{Venture capital experience}

Directors who represent venture capital firms have expertise in financing and a vested interest in the financial success of the firm and therefore are likely to be more informed and attentive to the firm's operations (Fried, Bruton, and Hisrich, 1998).

\subsubsection{Financial expertise}

The basis of company survival is profitability. Understanding financial and accounting aspects helps in analysing issues of profitability and net worth. Financial expertise on the board has been found to affect a range of firm issues, including debt strategies (Johnson, Schnatterly and Hill, 2012) and earnings management.

\subsubsection{Personal relationships between directors and the CEO}

Personal relationships between directors and the CEO may influence the advisory and access roles of these directors (Rhee and Lee, 2008). In a research by Johnson et al. (2012) the results note that findings do not yet provide clear answers to the basic question of what kinds of directors make the most effective board. Another shortcoming noted is that most board capital research utilizes secondary data, perhaps owing to the difficulty in generating adequate responses from direct inquiries of executives (Cycyota and Harrison, 2006).

\subsubsection{Personal relationships and affiliations}

Adler and Kwon (2002) state that social capital in the form of personal or loyalty relationships affects the incentives of directors' group dynamics and compromises their independence but also may facilitate more open communication with peers. These relationships can be based on a business tie, a perception of owing the CEO since the CEO was responsible for asking the board member to join the board or being friends or family members of the CEO. Such directors are likely to support the CEO in adopting policies that entrench the CEO like salary and increases of allowances. What then are the best sets of appropriate characteristics of directors from a stakeholder point of view?

\subsection{Women on boards of directors}

Heterogeneous groups produce higher quality decisions than homogeneous groups on complex tasks and generate more innovative solutions than homogeneous groups through cognitive conflict (Chen et al., 2005). Researchers have noted that the growing numbers of women and racial minority directors on boards have led to increased attention to social responsibility, charitable giving, and community relationships (Williams, 2003). In Norway legislation is mandating companies to appoint women to their corporate boards to achieve 40 per cent females within the next three years, and Sweden has implemented similar legislation with a target of 25 per cent female representation (Hoel, 2004). It is incumbent upon research to establish the utility value of women and how they can be capacitated to do better.

According to Adams and Ferreira (2009) the percentage of female directors in Canada, Japan and Europe is estimated to be $10.6 \%, 0.4 \%$, and $8.0 \%$, respectively. They further state that the situation is likely to change because boards around the world are under increasing pressure to choose female directors and many proposals for governance reform explicitly stress the importance of gender diversity in the boardroom. The given statistics are for countries with developed capital markets. Research should focus on how women representation on boards can be improved.

Based on a sample of US firms, researchers find that the proportion of women on the board is positively related to market performance based on Tobin's q (Carter et al., 2003). Using accounting-based performance, the positive association is found between ROA and the fraction of women on the board (Erhardt et al., 2003). The composition of women on the board and their contribution is an issue that needs further probing in a country like Zimbabwe. Stakeholder perceptions are also needed as they will make the role of women more understandable.

\subsection{Ubuntu / unhu in the boardroom}

The importance of the community (or stakeholders) is evident in the philosophy of 'unhu or ubuntu'. The term means 'I am because you are' or "I am, because we are; and since we are, therefore I am" (Mbiti, 1989, p. 110). Prinsloo (2000, p. 276) regards 'ubuntu unhu' as a form of African humanism as being sympathetic, caring, sensitive to the needs of others, being respectful, considerate, patient and kind". Prinsloo (2000) illustrates how 'unhu / ubuntu' can be expressed as 'participative management' and can even be used as a business management technique. Zimbabwean culture supports working as teams as evidenced by the sayings: Rume rimwe harikombi churu, chara chimwe hachitswanyi inda and kuwanda kwakanaka kunorambwa nemuroyi. These proverbs simply mean that one person cannot successfully work alone. The selection process should thus hinge on creating a team (board) that is humanistic, focused and hardworking in order to give value to shareholders and other stakeholders. 


\subsection{Board effectiveness}

An effective board requires non-executive directors to both support executives in their leadership of the business and to monitor and control their conduct (Shen, 2005). The key antecedents of non-executive directors' effectiveness are:

- the degree of independence (Monks and Minow, 2004),

- the level of knowledge and skills,

- The economic incentives to behave properly (Shen, 2005).

Creating board effectiveness and accountability is to bridge the gap between the myths about board role expectations and the realities of actual board task performance (Huse, 2005). Roberts et al (2005) opine that the key to board effectiveness lies in the degree to which non-executives acting individually and collectively are able to create accountability within the board in relation to both strategy and performance. They further argue that such accountability is in practice achieved through a wide variety of behaviours - challenging, questioning, probing, discussing, testing, informing, debating, exploring, encouraging - that are at the very heart of how nonexecutives seek to be effective. Forbes and Milliken (1999) define an effective board as one that can perform distinctive service and control activities successfully (task effectiveness) and yet continue working together (cohesiveness). They propose that the most effective boards will be characterized by high levels of interpersonal attraction (cohesiveness) and task-oriented disagreement (cognitive conflict).

\subsection{The influence of the Chief Executive Officer (CEO) on the board}

Agrawal and Chadha (2005) argue that a CEO's influence on the board can reduce the board's effectiveness in monitoring managers and the greater a CEO's influence on the board, the less likely the board is to suspect irregularities that a more independent board may have caught. Concerns about a CEO's influence on the board have led the New York Stock Exchange (NYSE) to propose that each board have a nominating or corporate governance committee that is comprised solely of independent directors (ibid).

Chief executive officers (CEOs) affect the quality of the information available to the board of directors and investors (e.g., Adams and Ferreira, 2007) and Song and Thakor, 2006) as well as corporate investment decisions. Their personal attributes and behavioral biases, such as overconfidence, affect both their informationprovision incentives as well as their investment decisions (Malmendier and Tate (2005). They also opine that a rational, risk-averse $\mathrm{CEO}$ under invests in projects relative to the shareholders' optimum.

\subsection{Non - executive directors (NEDs) and director independence on the board}

Edwards and Clough (2005) define an independent outsider as a director who is not a former employee, not a major shareholder, not holding a significant contractual, supplier or advisory relationship with the company and does not have any other significant interest in the company, which could negatively impact on the director's ability to act in the interests of the company. It is argued by the resource dependence theory (Pearce and Zahra, 1992) that the larger the number of non-executive directors on the board, the better they can fulfil their role in monitoring and controlling the actions of the executive directors, as well as providing a window to the outside world.

Directors who owe conflicting fiduciary obligations (for example, where they are on the boards of two competing companies) may breach their fiduciary duties to both companies (Ritchie, 2007). Ritchie (2007) contends that directors who are independent will lack relevant experience and will tend to manage the company more conservatively. Non-independent directors are more effective than independents because they have superior knowledge of the firm and industry compared to outside directors (ibid). Allock and Filatotchev (2010) find evidence of the good governance roles of independent directors, although their results are only weakly significant. This brings into question the selection processes for these directors, as well as the extent of their independence from the founding directors.

Those researchers who are in favour of more non-executive directors on the board base their arguments on two theories; agency and resource dependency. The premise of agency theory is that boards are needed to monitor and control the actions of directors due to their opportunistic behaviour (Haniffa and Cooke, 2000). Mangel and Singh (1993) believe that outside directors have more opportunity for control and face a more complex web of incentives, stemming directly from their responsibilities as directors and augmented by their equity position. In other words, non-executive directors are seen as the check and balance mechanism in enhancing boards' effectiveness.

In a mixed method study by Hooghiemstra and Manen (2004) on problems facing non-executive directors on issues of independence, findings were that although the majority agreed that monitoring is their main duty, they also expressed doubts whether they are really able to carry out this "watchdog role" effectively. The primary limitation is sought in the asymmetry of information which gives rise to the so-called "independence paradox": in obtaining adequate information non-executives are dependent on the executives they are expected to supervise and to be independent from. The results of the study by Hooghiemstra and 
Manen (2004) indicate the strategic involvement of directors, and the findings are also in line with a recent study by the Dutch Foundation on Corporate Governance (2002).

\section{Methodology}

The basis of this research is a literature review. A qualitative analysis is used to come up with findings and recommendations.

\section{Main Findings}

In spite of the introduction of corporate governance codes of the mould of the Sarbanes Oxley Act of 2002 (U.S.A.), The Combined Code of Corporate Governance (U.K.) and the King 3 Report of South Africa; corporate governance failures continue to plague the world. Corporate governance codes seem not to be the panacea to board failure. Answers are needed as this creates a research agenda especially for Africa, and particularly Zimbabwe where boards are failing to rein in errant executives.

The absence of a corporate governance code in Zimbabwe, thirty four years after political independence is worrying. Action is needed sooner than later. Research agendas should focus on improving corporate governance practices and also push for the publication of a code which is relevant to a developing country like Zimbabwe. The code acts as a reference point and offers guidance on corporate governance and board issues and processes.

The board sets the direction and approves the strategy of the organisation. The board selects, directs and rewards leadership. The board sets performance targets and provides risk oversight. This implies that boards should be strengthened and all processes that bring boards about should be strengthened and more Zimbabwean - specific research on board operations should be escalated.

Poor selection criteria lead to a poor board. Nominations of prospective board members by the Chief Executive Officer (CEO) curtail the oversight role of the board. The "old schoolboy" concept where board members are drawn from friends and former classmates is detrimental to proper oversight. Such board members protect CEOs rather than oversee their performances.

Directors who share the same characteristics as the CEO and other board members, have a high chance of selection to the board. In director selection, selectors are guided by the following characteristics: skills, knowledge, experience, social capital, reputation, other directorships and gender. Directors are also selected based on age, educational level, industry familiarity, financial expertise and venture capital experience. A diverse board could bring communication and interpersonal problems but could yield creativity and innovation from different experiences of directors. The CEO has influence on who is eventually selected to the board. Measures should be taken to ensure that the best directors populate boardrooms.

A boardroom must be characterised by ubuntu or African humanness which espouses the importance of the community or stakeholders. Ubuntu / unhu is about togetherness and being good to the outer world. Board members need to be selfless and should focus on doing their utmost to improve the value of the company.

\section{Recommendations}

There is need to establish how directors are selected in light of the high rate of company and board failures. Who selects directors and with what motive, is a key issue. Literature has shown that shareholders and other stakeholders have been ignored in the board selection process, yet they are the ones mostly affected if boards fail. There is need to determine how diverse boards should be like. The extent of director independence is essential as that has a bearing on the transaction of focused business on the board. Even where there are codes of good corporate governance practices, boards are failing and there is scope to find out why and proffer lasting solutions so that boards perform their oversight role with undoubted expertise.

\section{References}

[1]. Abdullah, S.N. (2004) Board Composition, CEO Duality and Performance among Malaysian Listed Companies. Journal of Corporate Governance, Issue 4, p. 47-61.

[2]. Adams, R.B and Ferreira, D. (2009) Corporate Women Directors International (CWDI) Women board directors of the Fortune Global 200. Journal of Financial Economics 94 291-309.

[3]. Agrawal, A. and Chadha, S. (2005) Corporate governance and accounting scandals. Journal of Law and Economics, Vol. 48 No. 2, pp. 371-406.

[4]. Ayogu, M. (2000) Africa in Comparative Corporate Governance. Hassan Toorawa Trust Occasional Paper \#6

[5]. Beasley, M. S. et al. (2009) The Audit Committee Oversight Process. Contemporary Accounting Research, 26(1): 65-122.

[6]. Blancheton et al (2011) Risk of liquidity and contagion of the crisis on the United States, United Kingdom and euro zone money markets. International Journal of Finance and Economics, Volume 17, Issue 2, pages 124-146, April 2012

[7]. Bohren, O. and Strom, R. O. (2010) Governance and politics: Regulating independence and

[8]. diversity in the boardroom. Journal of Business Finance and Accounting, 37: $1281-1308$.

[9]. Cadbury Committee (1992), Cadbury Committee Report: Financial Aspects of Corporate Governance. Basingstoke: Burgess Science Press. 
[10]. Carcello, J.V. et al (2011) Involvement in selecting board members, audit committee effectiveness and restatements. Contemporary Accounting Research, Vol 28.

[11]. Carpenter, M. A. et al. (2004) Upper echelons research revisited: Antecedents, elements and consequences of top management team composition. Journal of Management, $30749-778$.

[12]. Carter, D.A., B.J. Simkins and W.G. Simpson (2003), Corporate Governance, Board Diversity, and Firm Value, The Financial Review, Volume 38, 33-53.

[13]. Chen, Z., Cheung, Y., Stouraitis, A. and Wong, A. W. S. (2005) Ownership Concentration, Firm Performance, and Dividend Policy in Hong Kong, Pacific-Basin Finance Journal, 13(4), 431-449.

[14]. Cycyota, C.S. and Harrison, D.A. (2006) What (not) to expect when surveying top executives: A meta-analysis of top manager response rates and techniques over time. Organisational Research Methods, 9 (2): $133-160$.

[15]. Dalziel, T. Et al. (2011) An integrated agency-resource dependence view of the influence of directors' human and relational capital on firms' R \& D spending. Journal of Management Studies, 48: 1217 - 1242.

[16]. Dandira, M. (2011) Executive directors' contracts: poor performance rewarded, Business Strategy Series, Vol. 12 Issue 3, pp.156 163.

[17]. Deutsch, Y. and Ross, T. W. (2003) You are known by the directors you keep: Reputable directors as signalling mechanism for young firms. Management Science, 49: $1003-1017$.

[18]. Dutch Foundation Corporate Governance (2002) Corporate Governance in Nederland 2002. De Stand van Zaken. Amsterdam: Dutch Foundation Corporate Governance.

[19]. Edwards, M. and Clough, R. (2005) Corporate governance and performance: an exploration

[20]. of the connection in a public sector context: University of Canberra: Canberra.

[21]. Erhardt, N. L., Werbel, J.W. and C.B. Shrader, C.B. (2003) Board Director Diversity and Firm Financial Performance. Corporate Governance $11(2), 102-111$.

[22]. Fich, E. M. and White, L. J. (2003) CEO compensation and turnover: The effects of interlocked boards. Wake Forest Lake Review, 38: $935-959$.

[23]. Filatotchev, I. (2010) Corporate Governance and the Business Life Cycle: Edward Elgar.

[24]. Finkelstein, S. et al. (2009) Strategic leadership: Theory and research on executives, top management teams and boards. Oxford, UK: Oxford University Press.

[25]. Forbes, D. and Milliken, F. (1999) Cognition and corporate governance: Understanding boards of directors as strategic decision making groups. Academy of Management Review, 24, 489-505.

[26]. Fried, V. H. et al. (1998) Strategy and the board of directors in venture capital-backed firms. Journal of Business Venturing, 13 (6): $493-503$.

[27]. Golden, B.R. and Zajac, E. J. (2001) When will boards influence strategy? Inclination $x$ strategy = strategic change. Strategic Management Journal, 22: 1087 - 1111.

[28]. Haniffa, R. M., and Cooke, T. E. (2000) Culture, corporate governance disclosure in Malaysian corporations. Presented at the Asian AAA World Conference in Singapore.

[29]. Hashim, H.A. and Devi, S. (2008) Board independence, CEO duality accrual management: Malaysian evidence. Asian Journal of Business Accounting 1(1): 27-46.

[30]. Heenetigala, K. and Armstrong, A. (2009) The Impact of Corporate Governance on firm performance in an unstable economic and political environment: Evidence from Sri Lanka. Victoria University.

[31]. Hooghiemstra, R., and Van Manen, J. (2004). The Independence Paradox: (im) possibilities facing non-executive directors in The Netherlands. Corporate Governance: An International

[32]. Review, 12(3), 314-324.

[33]. Hoskisson, R. E. et al. (2009) Complementarity in monitoring and bonding: More intense monitoring leads to higher executive compensation. Academy of management Perspectives, 23 (2): 57-74.

[34]. Huse, M. (2005) Accountability and creating accountability: A framework for exploring behavioural perspectives of corporate governance. British Journal of Management, 16: S65-S79.

[35]. Jeter, L. (2003) Lessons for us all from WorldCom's fall. Charlotte Business Journal

[36]. Johnson, S. G. et al. (2013) Board composition beyond independence: social capital, human capital and demographics. Journal of Management, 39: $232-262$.

[37]. Makahamadze, T. et al. (2009) The role of traditional leaders in fostering democracy, justice and human rights in Zimbabwe. The African Anthropologist, Volume 16 Nos 1 and 2, pages 33-47.

[38]. Malmendier, U., Tate, G. (2005) CEO overconfidence and corporate investment. The Journal of Finance, Volume 6, pp 2661-2700.

[39]. Mangena, M. and Tauringana, V. (2007) Disclosure, corporate governance and foreign share ownership on the Zimbabwe Stock Exchange. Journal of International Financial management and Accounting, 18 (2): 53-85.

[40]. Mangel, R. and Singh, H. (1993) Ownership structure, board relations and CEO

[41]. compensation in large US corporations. Accounting and Business Research, 23 (sup 1), 339-

[42]. 350 .

[43]. Mbigi, L. and Maree, J. (1995) Ubuntu: The spirit of African Transformation management. Knowledge Resources: Pretoria.

[44]. Mbiti, J. S. (1990) African Religions and Philosophy: Pearson Education Limited.

[45]. Mooweon, R. and Lee, J. (2008) The signals outside directors send to foreign investors: Evidence from Korea. Corporate Governance: An International Review, 16: 14-51.

[46]. Nasir, N. M. and Abdullah, S.N. (2004) Voluntary disclosure and corporate governance

[47]. among financially distressed firms in Malaysia. Financial Reporting, Regulation and

[48]. Governance, 3(1), 1-39.

[49]. Nicholson, G. J. and Kiel, G.C. (2004) Breakthrough board performance: how to harness your board's intellectual capital[1], Corporate Governance, Vol. 4 Issue: 1 , pp. $5-23$.

[50]. Njanike, K. et al. (2011) Internal controls in ensuring good corporate governance in financial institutions. Annals of the University of Petrosani Economics, 11 (1).

[51]. Pearce, J.A. and Zahra, S.A. (1992) Board composition from a strategic contingency perspective. Journal of Management Studies, Vol. 29, pp. 411-38.

[52]. Philippe Haspeslagh, (2010) Corporate governance and the current crisis. Corporate Governance, Vol. 10 Issue: 4, pp.375 - 377.

[53]. Ritchie, F. (2007) Statistical Disclosure Control in a Research Environment. Mimeo: Office for National Statistics.

[54]. Roberts, J., McNulty, Y., and Stiles, P. (2005). Beyond agency conceptions of the work of non-executive director: Creating accountability in the boardroom. British Journal of Management, 16, 5-26. 
[55]. Rose, C. (2007) Does female representation influence firm performance? The Danish Evidence. Corporate Governance, 15: 404413.

[56]. Rossouw, G. J. (2005) Business Ethics and Corporate Governance in Africa, Business Society.

[57]. Shen, J. (2005) International training and development theory and reality, International Journal of Management Development, 24(7): 656-666.

[58]. Shivdasani, A. and Yermack, D. (1999) CEO involvement in the selection of new board members: An empirical analysis, Journal of Finance 54, 1829-1853.

[59]. Singh, V. (2007) Ethnic diversity on top corporate boards: A resource dependency perspective. International Journal of Human Resource Management, 18: 2128-2146.

[60]. Song, F. and Thakor, A.V. (2006) Information control, career concerns, and corporate governance, Journal of Finance 61, 18451896 .

[61]. Terjesen, S. et al. (2009) Women directors on corporate boards: A review and research agenda. Corporate Governance: An International Review, 17: 320-337.

[62]. The Herald of 3 March of 2014

[63]. Westphal, J. D. and Stern, I. (2007) Flattery will get you everywhere (especially if you are a male Caucasian): How ingratiation, boardroom behavior, and demographic minority status affect additional board appointments at U.S. companies. Academy of Management Journal, 50: 267-288.

[64]. Williams, R. J. (2003) Women on corporate boards of directors and their influence on corporate philanthropy. Journal of Business Ethics 42(1): 1-10.

[65]. Wincent, J. et al. (2010) Quality meets structure: Generalised Reciprocity and Firm-Level Advantage in Strategic Networks. Journal of Management Studies, 47: 597-624.

[66]. Withers, M. C. et al. (2012) A multidisciplinary review of the director selection literature. Journal of Management, 38(1): $243-277$.

[67]. Zimbabwe Companies Act Chapter 24:03

[68]. Zimbabwe Stock Exchange Listing requirements. 